\title{
Adequacy of decision-making based on each kidney function estimation method for Japanese living kidney donor candidates: a retrospective observational study
}

Koji Hashimoto ${ }^{1}$, Makoto Harada ${ }^{1}$, Yosuke Yamada', Mitsutoshi Sugano², Tomonori Minagawa ${ }^{3}$, Teruyuki Ogawa ${ }^{3}$, Osamu Ishizuka ${ }^{3}$ and Yuji Kamijo ${ }^{1 *}$

\begin{abstract}
Background: Living kidney transplantation comprises the majority of kidney transplantations in Japan. Living kidney donors should be assured of their own health. Therefore, Japanese guidelines define the criterion of kidney function for living donors. Glomerular filtration rates (GFR) $\geq 70 \mathrm{~mL} / \mathrm{min} / 1.73 \mathrm{~m}^{2}$ are required for marginal donors. The guidelines require that GFRs of donors be measured by the inulin (In) clearance method $\left(C_{\ln }\right)$ or the radioisotope method, but these methods can be substituted with the creatinine $(\mathrm{Cr})$ clearance method $\left(\mathrm{C}_{\mathrm{Cr}}\right)$. Methods for estimating kidney function are susceptible to error, and decision-making regarding donor eligibility could be affected by the estimation method used. We investigated the adequacy of decision-making based on kidney function estimation methods used in Japanese living kidney donor candidates by comparing $\mathrm{C}_{\mathrm{Cr}}$ or estimated GFR (eGFR), calculated by several equations, and $C_{\text {In }}$ as measured GFR (mGFR).
\end{abstract}

Methods: In total, 210 people, including 36 actual kidney donor candidates, who had both $C_{\ln }$ and $C_{C r}$ measured at Shinshu University Hospital from April 2011 to April 2015, were included. Cr and cystatin C (Cys) levels measured at the same time were used to calculate eGFR (eGFR $\mathrm{Cr}_{\mathrm{r}}$ and $\mathrm{sGFR} \mathrm{R}_{\mathrm{Cy} \text {, }}$ respectively). We evaluated the concordance rates of cases whose GFR levels were $\geq 70 \mathrm{~mL} / \mathrm{min} / 1.73 \mathrm{~m}^{2}$ in this study and assumed that they were living kidney donor candidates. Only kidney donor candidates underwent an additional sensitivity analysis.

Results: Median $C_{\ln }$ and $C_{C_{r}}$ were $55.5 \mathrm{~mL} / \mathrm{min} / 1.73 \mathrm{~m}^{2}$ and $68.0 \mathrm{~mL} / \mathrm{min} / 1.73 \mathrm{~m}^{2}$, respectively. $C_{\mathrm{cr}}$ had the highest tendency to overestimate kidney function. Some participants were incorrectly evaluated as adequate using $C_{\mathrm{Cr}_{r}}$ despite their mGFR being inadequate for living kidney donors according to the guidelines. These results were independent of sex or actual living kidney donor candidates. The average of eGFR $\mathrm{Cr}_{\mathrm{r}}$ and eGFR $\mathrm{R}_{\mathrm{s}}$ was well correlated with $C_{\text {In }}$.

Conclusions: Kidney function estimated by $C_{C r}$ is not equal to the mGFR. When using $C_{c r}$ as a kidney function estimation method to determine the adequacy of a living kidney donor, it should be noted that $C_{c r}$ overestimates kidney function. In evaluating adequacy for a marginal donor, GFR estimated by $C_{\text {In }}$ should be assessed.

Keywords: Kidney function, Living donors, Kidney transplantation, Decision making

\footnotetext{
*Correspondence: yujibeat@shinshu-u.ac.jp

'Department of Nephrology, Shinshu University School of Medicine, 3-1-1

Asahi, Matsumoto 390-8621, Japan

Full list of author information is available at the end of the article
}

(c) The Author(s). 2020 Open Access This article is distributed under the terms of the Creative Commons Attribution 4.0 International License (http://creativecommons.org/licenses/by/4.0/), which permits unrestricted use, distribution, and reproduction in any medium, provided you give appropriate credit to the original author(s) and the source, provide a link to the Creative Commons license, and indicate if changes were made. The Creative Commons Public Domain Dedication waiver (http://creativecommons.org/publicdomain/zero/1.0/) applies to the data made available in this article, unless otherwise stated. 


\section{Background}

The number of patients with end-stage kidney disease has been rising, and the number of patients who require kidney transplantation has also been increasing worldwide. Living kidney transplantation comprises the majority of kidney transplantations in Japan because of a lack of cadaveric kidney donors [1]. It is important that the kidney donor be assured of their own health before they are willing to donate a kidney. In particular, they need to be assured that they will not suffer kidney failure after they donate. Therefore, committees of each country performing kidney transplantation have established guidelines for living kidney donors.

The Japanese guidelines for living kidney donation define the criterion of adequate kidney function for the donor as a glomerular filtration rate (GFR) $\geq 80 \mathrm{~mL} /$ $\min / 1.73 \mathrm{~m}^{2}$ [2]. If the donor candidate has a lower function than the criterion, a GFR $\geq 70 \mathrm{~mL} / \mathrm{min} / 1.73 \mathrm{~m}^{2}$ is allowed as a marginal donor according to the guidelines. Moreover, the guidelines require that the donor candidate GFR be measured by the inulin clearance method $\left(\mathrm{C}_{\mathrm{In}}\right)$ or the radioisotope method but the creatinine clearance method $\left(\mathrm{C}_{\mathrm{Cr}}\right)$ can be substituted [2] Which method to adopt depends on each kidney transplant center in these circumstances. However, $\mathrm{C}_{\mathrm{Cr}}$ is known to overestimate kidney function among subjects with decreased GFR because creatinine $(\mathrm{Cr})$ can be secreted by renal tubular cells. Therefore, the Consensus Statement of the Amsterdam Forum on the Care of the Live Kidney Donor states that $\mathrm{C}_{\mathrm{Cr}}$ may under or overestimate GFR in patients with normal or near normal kidney function [3].

Other GFR estimation methods based on the estimation formula (eGFR) are simple and widely used but less accurate. An eGFR calculated using the Japanese equation for estimated GFR $\left(e G F R_{C r}\right)$ has a standard that $75 \%$ of the subjects tested fall within $\pm 30 \%$ of the real GFR [4]. Furthermore, GFR $_{\mathrm{Cr}}$ is susceptible to error. Although GFR estimation methods other than eGFR $_{\mathrm{Cr}}$ exist, differences among these methods and their potential impact regarding donor eligibility testing is not well known. Though $C_{\text {In }}$ is a gold standard method for estimating GFR, it is a challenge because of the required reagent preparation and the need for multiple blood and urine samples. Therefore, only a limited number of facilities conduct $C_{\text {In }}$ testing routinely.

Estimation methods for kidney function of living kidney donor candidates are potentially susceptible to error, and the decision-making regarding donor eligibility could be affected by the estimation method used. But the impact of these differences is not thoroughly known. In addition to this, there is no uniformity as different evaluation methods are used at each transplantation center. The evaluation of donor eligibility may not be a unified standard in Japan for these reasons. We conducted this study to investigate the adequacy of decisionmaking based on each kidney function estimation method for Japanese living kidney donor candidates through the comparison of $\mathrm{C}_{\mathrm{Cr}}$ or eGFR from several equations and $\mathrm{C}_{\mathrm{In}}$ as measured GFR (mGFR).

\section{Methods \\ Study design}

This study was conducted as a single-center retrospective observational study. All subjects who had both their $\mathrm{C}_{\text {In }}$ and $\mathrm{C}_{\mathrm{Cr}}$ measured within a 3-day period from April 2011 to April 2015 were included. The data of 210 participants were extracted for this study, which included 36 actual living kidney donor candidates. All 210 participants were included to detect differences between $C_{\text {In }}$ and several GFR estimation methods, because using only actual living kidney donor candidates was insufficient for statistical analysis. To verify whether the results obtained from the analysis of all 210 participants could apply to living kidney donor candidates, we performed a sensitivity analysis limited to actual living kidney donor candidates. Participants' characteristics and laboratory data were located and extracted from the medical records at Shinshu University Hospital. This study protocol was approved by the Shinshu University Ethical Committee (approval number 3384) and was conducted in accordance with the principles of the Declaration of Helsinki, as revised in 2013.

\section{Methods of measurement}

Serum creatinine $(\mathrm{Cr})$ was measured with an enzymatic method using a BM6070 auto biochemical analyzer (JEOL Ltd., Tokyo, Japan). The normal ranges of $\mathrm{Cr}$ at our institute were $0.65-1.07 \mathrm{mg} / \mathrm{dL}$ (males) and $0.46-0.79 \mathrm{mg} / \mathrm{dL}$ (females). Serum cystatin C (Cys) was measured with the latex immunoturbidimetric method using the same analyzer. The normal range of Cys at our institute was 0.60-0.98 $\mathrm{mg} / \mathrm{L} . \mathrm{C}_{\mathrm{Cr}}$ and eGFR were calculated using the following formula using $\mathrm{Cr}$ or Cys.

\section{$C_{\text {In }}$}

$\mathrm{C}_{\text {In }}$ was measured using the simple sampling strategy reported previously [5]. Subjects were asked to drink $500 \mathrm{~mL}$ water $15 \mathrm{~min}$ prior to infusion of inulin. A 1\% inulin (Fuji Yakuhin Co. Saitama, Japan) containing saline infusion was started at the pace of $300 \mathrm{~mL} /$ h. Thirty minutes after starting inulin administration, the pace of infusion was changed to $100 \mathrm{~mL} / \mathrm{h}$. Fortyfive minutes after inulin administration, subjects had to urinate completely to empty their bladder and hydrate with $180 \mathrm{~mL}$ water orally, after which a blood sample was collected. Blood and urine samples were collected $60 \mathrm{~min}$ later (105 min after starting inulin 
infusion). Measurements of plasma and urine inulin concentrations were performed using an enzymatic method. $C_{\text {In }}$ was calculated using the average of plasma inulin concentration at $45 \mathrm{~min}$ and $105 \mathrm{~min}$, as well as urine inulin concentration and urine volume. $C_{\text {In }}$ was calculated per $1.73 \mathrm{~m}^{2}$ body surface area to compare with other kidney function estimating tests as measured GFR. $C_{\text {In }}$ was finally calculated with the following formula.

$$
\mathrm{C}_{\mathrm{In}}\left(\mathrm{mL} / \mathrm{min} / 1.73 \mathrm{~m}^{2}\right)=\frac{\text { Urine-In }(\mathrm{mg} / \mathrm{dL}) \times \text { Urine Volume }(\mathrm{mL})}{\text { Plasma-In }(\mathrm{mg} / \mathrm{dL}) \times 60(\mathrm{~min})} \times \frac{1.73}{\mathrm{BSA}\left(\mathrm{m}^{2}\right)}
$$

$\mathrm{C}_{\mathrm{cr}}$

To calculate the $C_{C r}$, a 24-h urine collection was performed, and urine volume was recorded. Total amount of $\mathrm{Cr}$ evacuation and serum $\mathrm{Cr}$ was measured at the same time. The $C_{\mathrm{Cr}}$ value was calculated per $1.73 \mathrm{~m}^{2}$ body surface area to compare with other kidney function tests. $\mathrm{C}_{\mathrm{Cr}}$ was calculated by the following formula.

$$
\mathrm{C}_{\mathrm{Cr}}\left(\mathrm{mL} / \mathrm{min} / 1.73 \mathrm{~m}^{2}\right)=\frac{\text { Urine }-\mathrm{Cr}(\mathrm{mg} / \mathrm{dL}) \times \text { Urine Volume }(\mathrm{mL} / \text { day })}{\operatorname{Serum}-\mathrm{Cr}(\mathrm{mg} / \mathrm{dL}) \times 1440(\mathrm{~min})} \times \frac{1.73}{\mathrm{BSA}\left(\mathrm{m}^{2}\right)}
$$

\section{eGFR}

The eGFR was calculated using laboratory data collected at the time $\mathrm{C}_{\mathrm{Cr}}$ and $\mathrm{C}_{\mathrm{In}}$ were measured. We used the following formulas to calculate a Cr-based eGFR $\left(e^{-G F R}{ }_{C r}\right)$ and a Cys-based eGFR (eGFR $\left.{ }_{\text {Cys }}\right)$ [6, 7]. These formulas were targeted for Japanese adults and are used most widely in Japan.

$$
\mathrm{eGFR}_{\mathrm{Cr}}\left(\mathrm{mL} / \mathrm{min} / 1.73 \mathrm{~m}^{2}\right)=194 \times \mathrm{Cr}^{-1.094} \times \mathrm{Age}^{-0.287} \times
$$
0.739 (if female) [6];

$$
\begin{aligned}
& \mathrm{eGFR}_{\text {Cys }}\left(\mathrm{mL} / \mathrm{min} / 1.73 \mathrm{~m}^{2}\right) \\
& \text { Male eGFR }{ }_{\text {Cys }}=\left\{104 \times \text { Cys }^{-1.019} \times 0.996^{\text {Age }}\right\}-8[7] \\
& \text { Female eGFR } \text { Cys }=\left\{104 \times \mathrm{Cys}^{-1.019} \times 0.996^{\mathrm{Age}} \times 0.929\right\}-8[7]
\end{aligned}
$$

In addition to these equations, the average of eGFR $\mathrm{Cr}_{\mathrm{r}}$ and $e G R_{C y s}\left(e G F R_{C r+C y s}\right)$ was calculated and used for comparison, because it has been reported that eGFR $_{\mathrm{Cr}+\mathrm{Cys}}$ is more accurate [8].

$$
\operatorname{eGFR}_{\mathrm{Cr}+\mathrm{Cys}}\left(\mathrm{mL} / \mathrm{min} / 1.73 \mathrm{~m}^{2}\right)=\frac{\text { eGFR-Cr+eGFR-Cys }}{2}
$$

Moreover, we used another Cr-based GFR equation, The Chronic Kidney Disease Epidemiology Collaboration (CKD-EPI) equation (eGFR-CKDEPI $\mathrm{Cr}_{\mathrm{r}}$ ) in this study [9].

$$
\begin{aligned}
& \text { eGFR - CKDEPI }{ }_{\mathrm{Cr}}\left(\mathrm{mL} / \mathrm{min} / 1.73 \mathrm{~m}^{2}\right) \\
& \text { Male, } \mathrm{Cr} \leq 0.9 \mathrm{mg} / \mathrm{dL}, \mathrm{eGFR}-\mathrm{CKDEPI}_{\mathrm{Cr}}=141 \times\left(\frac{\mathrm{Cr}}{0.9}\right)^{-0.411} \times 0.993^{\text {Age }}
\end{aligned}
$$$$
\text { [9] }
$$

Male, $\mathrm{Cr}>0.9 \mathrm{mg} / \mathrm{dL}$, eGFR-CKDEPI $\mathrm{Cr}=141 \times\left(\frac{\mathrm{Cr}}{0.9}\right)^{-1.209} \times 0.993^{\text {Age }}$ [9] [9]

Female, $\mathrm{Cr} \leq 0.7 \mathrm{mg} / \mathrm{dL}$, eGFR-CKDEPI $\mathrm{Cr}=141 \times\left(\frac{\mathrm{Cr}}{0.9}\right)^{-0.329} \times 0.993^{\text {Age }}$

Female, $\mathrm{Cr}>0.7 \mathrm{mg} / \mathrm{dL}$, eGFR-CKDEPI $\mathrm{Cr}=141 \times\left(\frac{\mathrm{Cr}}{0.9}\right)^{-1.209} \times 0.993^{\mathrm{Age}}$ [9]

All eGFR data were presented as $\mathrm{mL} / \mathrm{min} / 1.73 \mathrm{~m}^{2}$ and used for comparison.

\section{Outcome}

We compared each kidney function estimate with $C_{\text {In }}$. Differences between eGFR and $C_{\text {In }}$ were assessed. Moreover, we evaluated the concordance rates of the cases whose GFR was determined to be $\geq 70 \mathrm{~mL} / \mathrm{min} / 1.73 \mathrm{~m}^{2}$, which is the Japanese marginal donor criterion, presuming the participants of this study to be kidney donor candidates.

\section{Statistical analysis}

All obtained data were statistically analyzed. Continuous variables were presented as medians and ranges (minimum-maximum), and a Mann-Whitney $U$ test or Wilcoxon signed-rank test was used to compare between groups. Categorized variables were presented as percentages, and a chi-squared test or a Fisher's exact test was used to detect between-group differences. SPSS software (ver. 22; IBM Corp., Armonk, NY USA) was used for these statistical analyses.

\section{Results}

\section{Participant characteristics}

Table 1 shows the characteristics of the 210 participants. Mean age was 52.5 years, and men accounted for $60 \%$ of all participants. Mean body surface area for men was $1.72 \mathrm{~m}^{2}$ and for women was $1.50 \mathrm{~m}^{2}$. Median $\mathrm{Cr}$ level was $1.13 \mathrm{mg} / \mathrm{dL}$, and median Cys level was $1.24 \mathrm{mg} / \mathrm{L}$. Median level of excreted urine protein was $0.5 \mathrm{~g} /$ day. Median volume of urine $\mathrm{Cr}$ excretion was $1025 \mathrm{mg} /$ day. Thirty-six participants were assessed as actual living kidney donor candidates. Although their body weights were significantly lower than all other participants, their serum albumin levels were significantly higher. Their $\mathrm{Cr}$ and Cys levels were significantly lower than all participants. In addition to these tendencies, their urinary protein excretion was lower. 
Table 1 Patient characteristics

\begin{tabular}{|c|c|c|c|c|c|c|}
\hline & All Participants & Male & Female & P1 & Kidney donor candidates & $\mathrm{P} 2$ \\
\hline$n$ & 210 & $126(60 \%)$ & $84(40 \%)$ & & 36 & \\
\hline Age & $52.5(16-85)$ & $57(16-85)$ & $39.5(16-83)$ & $<0.01$ & $50(20-76)$ & n.s. \\
\hline Height (cm) & $163(144-184)$ & $167(151-184)$ & $157(144-168)$ & $<0.01$ & $162(144-184)$ & n.s. \\
\hline Weight (kg) & $59.8(33.1-115.2)$ & $63.0(34.5-103.0)$ & $52.3(33.1-115.2)$ & $<0.01$ & $53.8(41.2-85.5)$ & $<0.05$ \\
\hline $\mathrm{BSA}\left(\mathrm{m}^{2}\right)$ & $1.63(1.20-2.20)$ & $1.72(1.28-2.13)$ & $1.50(1.20-2.20)$ & $<0.01$ & $1.59(1.28-2.00)$ & n.s. \\
\hline Diabetes, $n$ (\%) & $32(15 \%)$ & $26(21 \%)$ & $6(7 \%)$ & $<0.01$ & $5(14 \%)$ & n.s. \\
\hline Alb (g/dL) & $3.7(0.9-4.9)$ & $3.6(1.2-4.9)$ & $3.8(0.9-4.6)$ & n.s. & $3.9(3.4-4.5)$ & $<0.01$ \\
\hline $\mathrm{Cr}(\mathrm{mg} / \mathrm{dL})$ & $1.13(0.45-6.31)$ & $1.34(0.63-6.31)$ & $0.80(0.45-2.62)$ & $<0.01$ & $0.86(0.48-1.19)$ & $<0.01$ \\
\hline Cys (mg/L) & $1.24(0.52-5.67)$ & $1.45(0.52-5.67)$ & $0.98(0.53-2.37)$ & $<0.01$ & $0.96(0.58-1.64)$ & $<0.01$ \\
\hline U-TP (g/day) & $0.5(0-11.4)$ & $0.7(0-11.4)$ & $0.3(0-8.4)$ & $<0.05$ & $0(0-0.16)$ & $<0.01$ \\
\hline $\mathrm{U}-\mathrm{Cr}$ (mg/day) & $1025(413-2012)$ & $1186(568-2012)$ & $889(413-1431)$ & $<0.05$ & $936(630-1783)$ & n.s. \\
\hline
\end{tabular}

Continuous variables were presented as medians and ranges (minimum-maximum). Mann-Whitney $U$ test was used to compare between groups. Categorized variables were presented as percentages and chi-squared tests were used to detect between-group difference. P1 was the result comparing between male and female. P2 was the result comparing between living kidney donor candidates and all participants. BSA body surface area, Alb albumin, $C r$ creatinine, Cys cystatin $C$, $U$-TP total urine protein, $U-C r$ urine creatinine, n.s. no significance

\section{Comparison between $C_{\ln }$ and other kidney function estimation tests}

Results of the comparison between $\mathrm{C}_{\text {In }}$ and other kidney function estimation tests using all participant data are shown in Table 2. Compared with $\mathrm{C}_{\mathrm{In}}, \mathrm{C}_{\mathrm{Cr}}$-estimated kidney function results were the highest among the results of all kidney function estimation tests. Kidney function estimated by eGFR ${ }_{C y s}$ and eGFR-CKDEPI $I_{C r}$ was significantly higher than that estimated by $\mathrm{C}_{\text {In }}$. In contrast, kidney function estimated by eGFR $\mathrm{Cr}_{\text {r }}$ was significantly lower than that estimated by $C_{\text {In }}$. Kidney function estimated by eGFR $\mathrm{Cr}_{\mathrm{C}+\mathrm{Cys}}$ and $\mathrm{C}_{\mathrm{In}}$ showed no significant difference.

To evaluate the accuracy of each test method, we calculated the percentage of estimates falling within $\pm 30 \%$ of mGFR (P30), the percentage falling within \pm $10 \%$ of mGFR (P10), and the absolute error between $\mathrm{C}_{\text {In }}$ and the other eGFR methods. eGFR $\mathrm{Cr}_{\mathrm{C}+\mathrm{Cys}}$ showed the highest accuracy for both P10 and P30 and the lowest error, whereas $\mathrm{C}_{\mathrm{Cr}}$ showed the lowest accuracy for P30 (57\%).

\section{Evaluation of kidney donor eligibility data using each kidney function estimation test}

Figure 1 shows scatter plots for $C_{\text {In }}$ and other kidney function estimation models. Study participants' $\mathrm{C}_{\text {In }}$ was widely distributed from chronic kidney disease (CKD) stage 1 to stage 5 .

Figure 1a shows the relationship between $C_{\text {In }}$ and $\mathrm{C}_{\mathrm{Cr}}$. The correlation between $\mathrm{C}_{\mathrm{In}}$ and $\mathrm{C}_{\mathrm{Cr}}$ was determined to be good $(r=0.889)$, but the values of $\mathrm{C}_{\mathrm{Cr}}$ were greater than those of $\mathrm{C}_{\text {In }}$ from low GFR to high GFR. This suggests that $C_{C r}$ estimates higher kidney function, without regard to GFR level. The number of cases in which GFR was measured by $\mathrm{C}_{\text {In }}$ to be $\geq 70$ $\mathrm{mL} / \mathrm{min} / 1.73 \mathrm{~m}^{2}$ was 81 . However, the number of cases in which GFR was estimated by $\mathrm{C}_{\mathrm{Cr}}$ to be $\geq 70 \mathrm{~mL} /$ $\mathrm{min} / 1.73 \mathrm{~m}^{2}$ increased to 100 . Among these 100 cases, the number of cases in which the GFR measured by $\mathrm{C}_{\text {In }}$ was $<70 \mathrm{~mL} / \mathrm{min} / 1.73 \mathrm{~m}^{2}$ was 23 . Therefore, $23 \%$ of candidates were incorrectly evaluated as adequate using $\mathrm{C}_{\mathrm{Cr}}$ despite the true GFR being inadequate for a living

Table 2 Comparison of GFR estimation methods to inulin clearance

\begin{tabular}{llllll}
\hline GFR estimation methods $(n=210)$ & Value $\left(\mathrm{mL} / \mathrm{min} / 1.73 \mathrm{~m}^{2}\right)$ & $p$ & $P 10$ & P30 & Absolute error $\left.\left(\mathrm{mL} / \mathrm{min}^{\prime} 1.73 \mathrm{~m}\right)^{2}\right)$ \\
\hline$C_{\text {In }}$ & $55.5(6.0-147.0)$ & Reference & & & $10.6(-50.5-78.4)$ \\
$C_{C r}$ & $68.0(8.5-167.3)$ & $<0.01$ & $24 \%$ & $57 \%$ & $-5.0(-56.2-41.4)$ \\
eGFR $_{C r}$ & $51.0(7.9-144.4)$ & $<0.01$ & $26 \%$ & $71 \%$ & $3.0(-51.0-57.5)$ \\
eGFR $_{C y s}$ & $60.0(5.7-181.2)$ & $<0.05$ & $24 \%$ & $68 \%$ & $-0.6(-41.1-48.9)$ \\
eGFR $_{C r+C y s}$ & $54.8(7.3-153.1)$ & n.s. & $35 \%$ & $78 \%$ & $-2.4(-46.8-47.4)$
\end{tabular}

Continuous variables were presented as medians and ranges (minimum-maximum) and Wilcoxon signed-rank test was used to compare between-groups. GFR glomerular filtration rate; eGFR estimated GFR based on $\mathrm{Cr}$ (creatinine) Cys (cystatin C), $\mathrm{Cr}+\mathrm{Cys}$ (an average of $\mathrm{Cr}+\mathrm{Cys}_{\text {), or } \mathrm{CKDEPI}} \mathrm{Cr}$ (a Cr-based equation from The Chronic Kidney Disease Epidemiology Collaboration ([CKD-EPI]); $C_{l n}$ inulin clearance; $C_{C r}$ creatinine clearance; $P 10$ percentage of estimates falling within $\pm 10 \%$ of measured GFR (mGFR); P30, percentage of estimates falling within $\pm 30 \%$ of $\mathrm{mGFR}$ 
a. $\mathrm{C}_{\mathrm{In}}$ and $\mathrm{C}_{\mathrm{Cr}}$

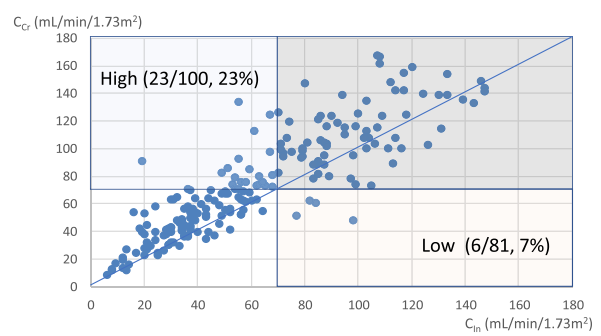

C. $C_{\text {In }}$ and eGFR

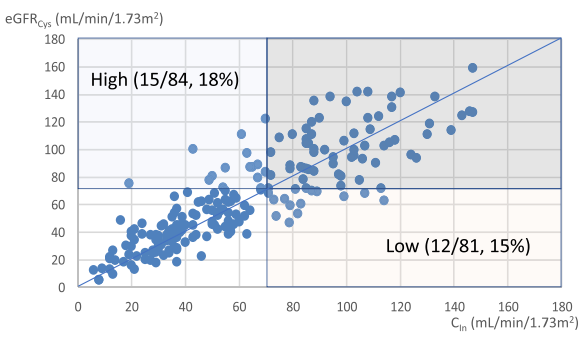

e. $C_{\ln }$ and eGFR-CKDEPI $C r$

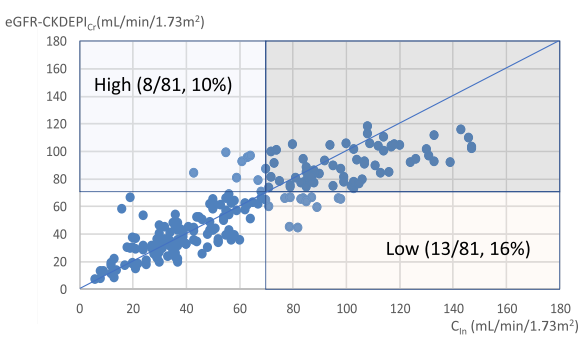

b. $\mathrm{C}_{\text {In }}$ and $\mathrm{eGFR}$ Cr

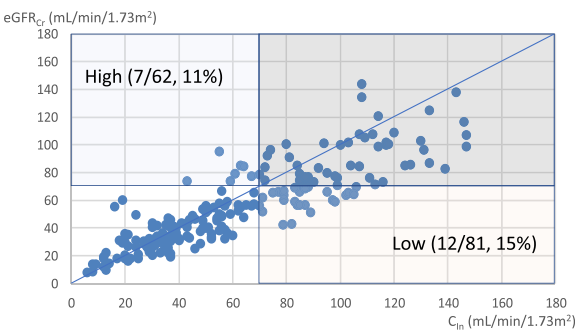

d. $C_{\text {In }}$ and eGFR $\mathrm{Cr}_{\mathrm{r}+\mathrm{Cys}}$

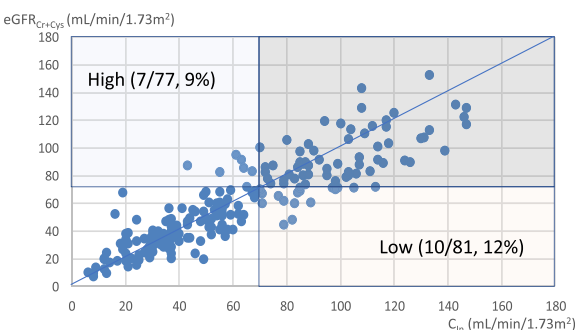

Fig. 1 Relationships of GFR estimation method and Inulin clearance. Figure 1 shows scatter plots for $C_{\text {In }}$ and other kidney function estimation models. a Cln and CCr, b Cln and eGFRCr, c Cln and eGFRCys, d Cln and eGFRCr+Cys, e Cln and eGFR-CKDEPICr. For reference, auxiliary line which equal to $C_{\text {In }}$ was presented. Abbreviations: GFR glomerular filtration rate; eGFR estimated GFR based on Cr (creatinine) Cys (cystatin C), $\mathrm{Cr}+$ Cys (an average of $\mathrm{Cr}+\mathrm{Cys}$ ), or $\mathrm{CKDEPI}_{\mathrm{Cr}}$ (a Cr-based equation from The Chronic Kidney Disease Epidemiology Collaboration ([CKD-EPI]); $C_{\text {In }}$ inulin clearance; $C_{C r}$ creatinine clearance

kidney donor. In contrast, lower kidney function was estimated using $\mathrm{C}_{\mathrm{Cr}}$ in six (7\%) of the 81 cases in which GFR measured by $\mathrm{C}_{\mathrm{In}} \geq 70 \mathrm{~mL} / \mathrm{min} / 1.73 \mathrm{~m}^{2}$.

Figure $1 \mathrm{~b}$ shows the relationship between $C_{\text {In }}$ and eGFR $_{\mathrm{Cr}}$. A good correlation was observed between $\mathrm{C}_{\mathrm{In}}$ and eGFR $_{\mathrm{Cr}}(r=0.888)$. The correlation between $\mathrm{C}_{\text {In }}$ and eGFR $_{\mathrm{Cr}}$ was mostly good in patients with GFR < $60 \mathrm{~mL} / \mathrm{min} / 1.73 \mathrm{~m}^{2}$, which was the definition of CKD, but eGFR $_{C r}$ tended to underestimate kidney function in patients with functionally normal kidneys. If $\mathrm{eGFR}_{\mathrm{Cr}}$ was used to evaluate the donor adequacy of the participants in this study, kidney function was overestimated in $7 / 62$ cases (11\%) and underestimated in $12 / 81$ cases (15\%), compared to that estimated using $\mathrm{C}_{\mathrm{In}}$.

Figure 1c shows the relationship between $C_{\text {In }}$ and eGFR $_{\text {Cys }}$. The relationship between $C_{\text {In }}$ and GGFR $_{\text {Cys }}$ displayed great variation, and the correlation between
$\mathrm{C}_{\text {In }}$ and eGFR $_{\text {Cys }}$ was worse than that between the other kidney function tests $(r=0.882)$. If eGFR $_{\text {Cys }}$ was used to evaluate the donor adequacy of the participants in this study, kidney function was overestimated in $15 / 84$ cases (18\%) and underestimated in 12/81 cases (15\%), compared to that estimated using $\mathrm{C}_{\mathrm{In}}$.

Figure $1 \mathrm{~d}$ shows the relationship between $\mathrm{C}_{\mathrm{In}}$ and eGFR $_{\mathrm{Cr}+\mathrm{Cys}}$. The average of eGFRCr and eGFRCys improved the underestimation due to eGFRCr and the variation due to eGFRCys. The best correlation was observed between $\mathrm{C}_{\mathrm{In}}$ and $\mathrm{eGFR}_{\mathrm{Cr}+\mathrm{Cys}}(r=0.903)$. If eGFR $_{\mathrm{Cr}+\mathrm{Cys}}$ was used to evaluate donor adequacy of participants in this study, kidney function was overestimated in $7 / 77$ cases (9\%) and underestimated in 10/81 cases $(12 \%)$, compared to that estimated using $\mathrm{C}_{\mathrm{In}}$.

Figure 1e shows the relationship between $\mathrm{C}_{\text {In }}$ and eGFR-CKDEPI $\mathrm{Cr}_{\mathrm{r}}$. A good correlation was observed between $\mathrm{C}_{\text {In }}$ and eGFR-CKDEPI $\mathrm{Cr}(r=0.890)$. The 


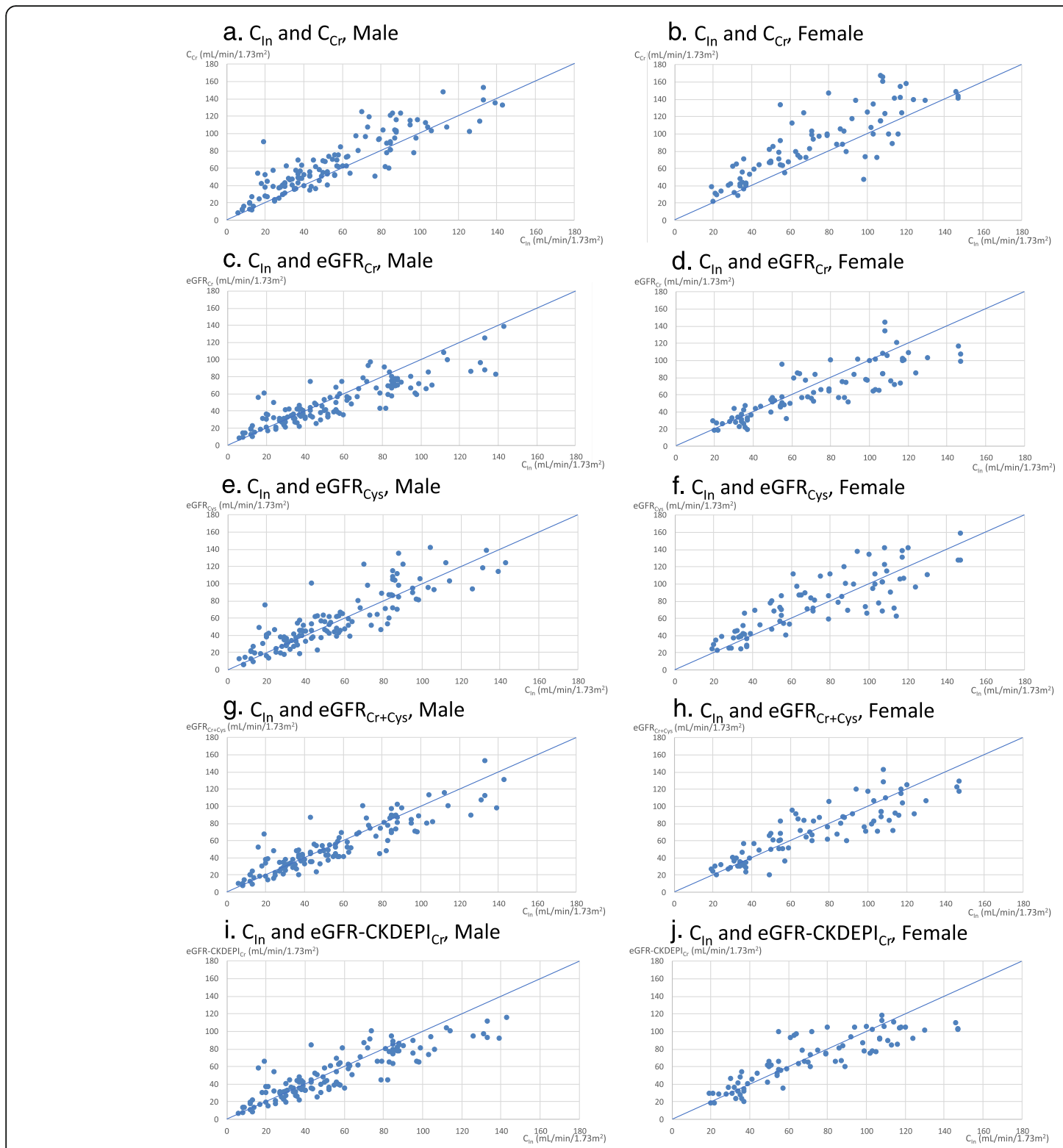

Fig. 2 Impact of sex on GFR estimation accuracy. Figure 2 shows scatter plots for $C_{\ln }$ and other kidney function estimation models dividing into sex. a Cln and CCr, male, $\mathbf{b}$ Cln and CCr, female, $\mathbf{c} C \mathrm{ln}$ and eGFRCr, male, $\mathbf{d}$ Cln and eGFRCr, female, e Cln and eGFRCys, male, f $\mathrm{fln}$ and eGFRCys, female, $\mathbf{g}$ Cln and eGFRCr+Cys, male, $\mathbf{h}$ CIn and eGFRCr+Cys, female, $\mathbf{i}$ Cln and eGFR-CKDEPICr, male, $\mathbf{j}$ Cln and eGFR-CKDEPICr, female. For reference, auxiliary line which equal to $C_{\text {In }}$ was presented. Abbreviations: GFR glomerular filtration rate; eGFR estimated GFR based on $\mathrm{Cr}$ (creatinine) Cys (cystatin C), $\mathrm{Cr}+\mathrm{Cys}$ (an average of Cr + Cys), or $C_{K D E P I} I_{r}\left(a\right.$ Cr-based equation from The Chronic Kidney Disease Epidemiology Collaboration ([CKD-EPI]); $C_{\text {In }}$ inulin clearance; $C_{C r}$ creatinine clearance

accuracy of eGFR-CKDEPI $\mathrm{Cr}_{\mathrm{r}}$ was mostly good for CKD, but eGFR-CKDEPI $\mathrm{Cr}_{\mathrm{r}}$ tended to underestimate kidney function in patients with functionally normal kidneys. If eGFR-CKDEPI $\mathrm{Cr}_{\mathrm{Cr}}$ was used to evaluate participant donor adequacy in this study, kidney function was overestimated in $8 / 81$ cases $(10 \%)$ and underestimated in $12 / 81$ cases $(16 \%)$, compared to that estimated using $C_{\text {In }}$.

Among the several kidney function estimation tests conducted in this study, $\mathrm{CCr}$ had the highest tendency to overestimate kidney function, and $\mathrm{C}_{\mathrm{Cr}}$ showed a tendency to estimate kidney function the highest.

\section{Impact of sex on estimation accuracy}

Some GFR estimation formulas use different coefficients in the case of a female, because males and females have different average body sizes and body components, such as muscle volume. Therefore, we investigated whether differences of sex affected relationships between 
estimated kidney function and $C_{\text {In }}$ (Fig. 2). The results showed that females had greater a variation than males in each relationship. Especially in the relationship between $\mathrm{C}_{\mathrm{Cr}}$ and $\mathrm{C}_{\text {In }}$, females tended to present higher $\mathrm{C}_{\mathrm{Cr}}$ than $\mathrm{C}_{\mathrm{In}}$ as well as greater variation.

\section{Impact of the amount of creatinine excretion on estimation accuracy}

Because urine $\mathrm{Cr}$ excretion differed widely among participants, we checked whether GFR estimation accuracy is affected by urine $\mathrm{Cr}$ excretion. We divided participants into two groups with a median $\mathrm{Cr}$ excretion of $1025 \mathrm{mg} /$ day and compared the two groups. Male sex was predominant and body surface area was significantly large in the high $\mathrm{Cr}$ excretion group. The relationships between $C_{\text {In }}$ and each GFR estimation method for each group are shown in Appendix A. Since $C_{\text {In }}$ was significantly different between the two groups, we evaluated accuracy by comparing errors between the GFR estimation methods and $C_{\text {In }}$. The results are presented in Table 3. The kidney function values were higher with $C_{C r}$ than with $C_{I n}$, regardless of $\mathrm{Cr}$ excretion. eGFR $\mathrm{Cr}_{\mathrm{r}}$ was significantly lower in the high $\mathrm{Cr}$ excretion group. Accuracy of eGFR $\mathrm{Cys}_{\mathrm{s}}$ was not affected by $\mathrm{Cr}$ excretion. Errors between eGFR $\mathrm{Cr}+\mathrm{Cys}$ and $\mathrm{C}_{\mathrm{In}}$ were small regardless of $\mathrm{Cr}$ excretion. eGFR-CKDEPI $\mathrm{Cr}_{\mathrm{r}}$ was underestimated in the high $\mathrm{Cr}$ excretion group.

\section{Evaluation in living kidney donor candidates}

This study included participants with proteinuria or obviously low kidney function, who could not be considered originally as living kidney donors. Therefore, we performed a sensitivity analysis in only living kidney donor candidates (Fig. 3). A total of 36 subjects were included. Median $\mathrm{C}_{\mathrm{Cr}}$ was $87.1 \mathrm{~mL} / \mathrm{min} / 1.73 \mathrm{~m}^{2}$, and median $\mathrm{C}_{\text {In }}$ was $85.0 \mathrm{~mL} / \mathrm{min} / 1.73 \mathrm{~m}^{2}$. Median $\mathrm{C}_{\mathrm{Cr}}$ was significantly higher than that of $\mathrm{C}_{\mathrm{In}}$ in these donor candidates. In $15 \%$ of these cases, the levels were $\geq 70 \mathrm{~mL} /$ $\mathrm{min} / 1.73 \mathrm{~m}^{2}$ when using $\mathrm{C}_{\mathrm{Cr}}$, but the levels were $<70$ $\mathrm{mL} / \mathrm{min} / 1.73 \mathrm{~m}^{2}$ when using $C_{\mathrm{In}}$, illustrating how $\mathrm{C}_{\mathrm{Cr}}$ overestimates kidney function. Median eGFR $\mathrm{Cr}_{\mathrm{Cr}}$ was 66.7 $\mathrm{mL} / \mathrm{min} / 1.73 \mathrm{~m}^{2}$, which was significantly lower than that using $\mathrm{C}_{\mathrm{In}}$. Concerning the evaluation of living donor adequacy, kidney function was overestimated in $6 \%$ of cases and underestimated in $27 \%$ cases. Median eGFR $\mathrm{Cys}_{\mathrm{s}}$ was $75.1 \mathrm{~mL} / \mathrm{min} / 1.73 \mathrm{~m}^{2}$, which showed no significant difference compared to $\mathrm{C}_{\mathrm{In}}$. Concerning the evaluation of living donor adequacy, kidney function was overestimated in $10 \%$ of cases and underestimated in $10 \%$ of cases. Median eGFR $\mathrm{Cr}_{\mathrm{C} \text { Cys }}$ was $71.4 \mathrm{~mL} / \mathrm{min} / 1.73 \mathrm{~m}^{2}$, which presented no significant difference with $\mathrm{C}_{\text {In }}$. Overall, kidney function was overestimated in $5 \%$ of cases and underestimated in $18 \%$ of cases. Median eGFRCKDEPI $_{\mathrm{Cr}}$ was $75.6 \mathrm{~mL} / \mathrm{min} / 1.73 \mathrm{~m}^{2}$, which did not imply significant differences with $C_{\text {In }}$. However,

Table 3 Impact of creatinine excretion

\begin{tabular}{|c|c|c|c|c|}
\hline & Total & Low $\mathrm{Cr}$ excretion & High $\mathrm{Cr}$ excretion & $P$ \\
\hline$n$ & 210 & 105 & 105 & \\
\hline Male (\%) & $126(60 \%)$ & $41(39 \%)$ & $85(81 \%)$ & $<0.01$ \\
\hline Age & $52.5(16-85)$ & $57(16-85)$ & $47(17-77)$ & $<0.01$ \\
\hline $\mathrm{BSA}\left(\mathrm{m}^{2}\right)$ & $1.63(1.20-2.20)$ & $1.52(1.20-2.13)$ & $1.73(1.46-2.20)$ & $<0.01$ \\
\hline $\mathrm{U}-\mathrm{Cr}$ (mg/day) & $1025(413-2012)$ & $843(413-1019)$ & $1260(1031-2012)$ & $<0.01$ \\
\hline $\mathrm{Cr}(\mathrm{mg} / \mathrm{dL})$ & $1.13(0.45-6.31)$ & $1.00(0.45-6.31)$ & $0.80(0.45-2.62)$ & n.s. \\
\hline Cys (mg/L) & $1.24(0.52-5.67)$ & $1.27(0.60-5.67)$ & $0.98(0.52-2.37)$ & n.s. \\
\hline$C_{\ln }\left(\mathrm{mL} / \mathrm{min} / 1.73 \mathrm{~m}^{2}\right)$ & $55.5(6.0-147.0)$ & $49.0(6.0-147.0)$ & $61.0(19.0-147.0)$ & $<0.01$ \\
\hline $\mathrm{C}_{\mathrm{Cr}}\left(\mathrm{mL} / \mathrm{min} / 1.73 \mathrm{~m}^{2}\right)$ & $68.0(8.5-167.3)$ & $57.5(8.5-167.3)$ & $75.7(24.1-158.7)$ & $<0.01$ \\
\hline$e G F R_{c r}\left(\mathrm{~mL} / \mathrm{min} / 1.73 \mathrm{~m}^{2}\right)$ & $51.0(7.9-144.4)$ & $48.2(7.9-144.4)$ & $55.0(16.2-138.1)$ & n.s. \\
\hline $\operatorname{eGFR}_{\text {Cys }}\left(\mathrm{mL} / \mathrm{min} / 1.73 \mathrm{~m}^{2}\right)$ & $60.0(5.7-181.2)$ & $53.0(5.7-142.0)$ & $62.1(13.2-181.2)$ & $<0.05$ \\
\hline $\operatorname{eGFR}_{\mathrm{Cr}+\mathrm{Cys}}\left(\mathrm{mL} / \mathrm{min} / 1.73 \mathrm{~m}^{2}\right)$ & $54.8(7.3-153.1)$ & $51.6(7.3-143.2)$ & $59.9(14.7-153.1)$ & n.s. \\
\hline eGFR-CKDEPI $\mathrm{Cr}_{\mathrm{r}}\left(\mathrm{mL} / \mathrm{min} / 1.73 \mathrm{~m}^{2}\right)$ & $57.7(7.1-118.4)$ & $54.1(7.1-118.4)$ & $61.3(15.1-116.1)$ & n.s. \\
\hline $\mathrm{C}_{\mathrm{Cr}}-\mathrm{C}_{\mathrm{In}}\left(\mathrm{mL} / \mathrm{min} / 1.73 \mathrm{~m}^{2}\right)$ & $10.6(-50.5-78.4)$ & $8.5(-50.5-78.4)$ & $12.6(-23.4-71.8)$ & n.s. \\
\hline $\mathrm{eGFR}_{\mathrm{Cr}}-\mathrm{C}_{\mathrm{In}}\left(\mathrm{mL} / \mathrm{min} / 1.73 \mathrm{~m}^{2}\right)$ & $-5.0(-56.2-41.4)$ & $0.3(-42.4-40.3)$ & $-10.0(-56.2-41.4)$ & $<0.01$ \\
\hline $\mathrm{eGFR}_{\text {Cys }}{ }^{-} C_{\mathrm{In}}\left(\mathrm{mL} / \mathrm{min} / 1.73 \mathrm{~m}^{2}\right)$ & $3.0(-51.0-57.5)$ & $2.9(-51.0-57.5)$ & $4.2(-32.1-56.3)$ & n.s. \\
\hline  & $-0.6(-41.1-48.9)$ & $0.4(-41.1-44.2)$ & $-1.7(-40.5-48.9)$ & n.s. \\
\hline eGFR-CKDEPI $\mathrm{Cr}_{\mathrm{r}} \mathrm{C}_{\mathrm{In}}\left(\mathrm{mL} / \mathrm{min} / 1.73 \mathrm{~m}^{2}\right)$ & $-2.4(-46.8-47.4)$ & $-0.4(-44.6-44.6)$ & $-7.0(-46.8-47.4)$ & $<0.01$ \\
\hline
\end{tabular}

Continuous variables were presented as medians and ranges (minimum-maximum). Mann-Whitney $U$ test was used to compare between groups. Categorized variables were presented as percentages and chi-squared tests were used to detect between-group difference. GFR glomerular filtration rate; eGFR estimated GFR based on $\mathrm{Cr}$ (creatinine) Cys (cystatin C), $\mathrm{Cr}+\mathrm{Cys}$ (an average of $\mathrm{Cr}+\mathrm{Cys}$ ), or CKDEPI $\mathrm{Cr}_{\mathrm{r}}$ (a Cr-based equation from The Chronic Kidney Disease Epidemiology Collaboration ([CKD-EPI]); $C_{I n}$ inulin clearance; $C_{C r}$ creatinine clearance; n.s. no significance 


\section{a. $\mathrm{C}_{\ln }$ and $\mathrm{C}_{\mathrm{Cr}}$}

$c_{G r}\left(\mathrm{~mL} / \mathrm{min} / .173 \mathrm{~m}^{2}\right)$



C. $C_{\text {In }}$ and eGFR Cys



b. $C_{\ln }$ and eGFR $_{\mathrm{Cr}}$

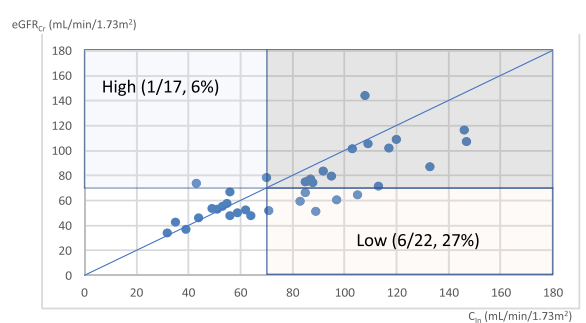

d. $C_{\text {In }}$ and eGFR $\mathrm{Cr}_{\mathrm{C}+\mathrm{Cys}}$



e. $C_{\text {In }}$ and eGFR-CKDEPI ${ }_{C r}$

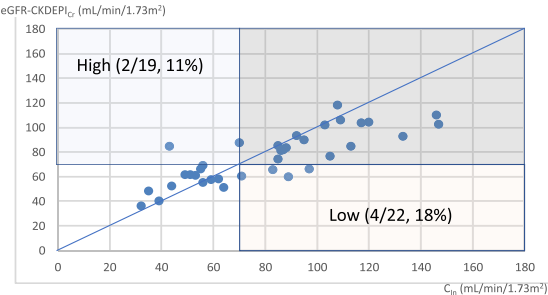

Fig. 3 GFR estimation methods in living kidney donor candidates. Figure 3 shows scatter plots for $C_{\ln }$ and other kidney function estimation models in living kidney donor candidates. a $\mathrm{Cln}$ and CCr, b Cln and eGFRCr, c Cln and eGFRCys, $\mathbf{d} \mathrm{Cln}$ and eGFRCr+Cys, e Cln and eGFR-CKDEPICr. For reference, auxiliary line which equal to $C_{\text {In }}$ was presented. Abbreviations: GFR glomerular filtration rate; eGFR estimated GFR based on $\mathrm{Cr}$ (creatinine) Cys (cystatin C), $\mathrm{Cr}+\mathrm{Cys}$ (an average of $\mathrm{Cr}+\mathrm{Cys}$ ), or CKDEPI $\mathrm{Cr}$ (a Cr-based equation from The Chronic Kidney Disease Epidemiology Collaboration ([CKD-EPI]); $C_{\text {ln, }}$ inulin clearance; $C_{C r}$ creatinine clearance

concerning the evaluation of living donor adequacy, kidney function was overestimated in $11 \%$ and underestimated in $18 \%$ of cases.

$\mathrm{C}_{\mathrm{Cr}}$ had the highest percentage in terms of overestimation of kidney function for classifying adequate donors in actual living kidney donor candidates.

\section{Discussion}

In this study, we investigated the relationships between mGFR using $C_{\text {In }}$ and several kidney function estimation tests and evaluated the impact of these tests in determining the adequacy for living kidney donors. Our findings reveal that $C_{C r}$ overestimates kidney function the most when compared with $\mathrm{eGFR}_{\mathrm{Cr}}$, eGFR $\mathrm{Cys}_{\mathrm{s}}$, eGFR $_{\mathrm{Cr}+\mathrm{Cys}}$, and eGFR-CKDEPI. Estimated kidney function obtained using $\mathrm{C}_{\mathrm{Cr}}$ is not equal to mGFR. Therefore, there is a risk that living kidney donor candidates with insufficient kidney function are falsely evaluated as adequate for kidney donation when $\mathrm{C}_{\mathrm{Cr}}$ is used. A previous study reported that $\mathrm{C}_{\mathrm{Cr}}$ overestimated the GFR; especially in cases with low GFR, the $\mathrm{C}_{\mathrm{Cr}}$ showed a marked tendency to overestimate the GFR [10]. This phenomenon is thought to occur due to creatinine not only being filtrated through the glomeruli but also excreted by the renal tubules. As for estimating GFR using $\mathrm{C}_{\mathrm{Cr}}$, the Japanese guidebook for CKD in 2012 described that $\mathrm{C}_{\mathrm{Cr}}$ was $30 \%$ higher than mGFR and needed to be multiplied by the coefficient 0.715 for converting to GFR [4]. According to this guidebook, the formula of GFR = $0.715 \times \mathrm{C}_{\mathrm{Cr}}$ can be established. Using this formula could decrease the overestimation using $\mathrm{C}_{\mathrm{Cr}}$, but the Guidelines for Japanese Living Kidney Donors has not included this conversion [2]. Therefore, it is not known whether or not this converting formula is being used in the clinical setting. If this converting formula is applied to participants of this study, the number of cases of 
overestimation decreased to $3 / 59$ cases (5\%). However, using that same converting formula, the number of cases of underestimation increased to $25 / 81$ cases (31\%). The coefficient 0.715 encouraged underestimation for donors in this study. The coefficient 0.715 could be too low for the normal GFR population, so further study is needed. Kidney donations from candidates with insufficient GFR could not only lead to poorer transplanted kidney function but this could also adversely affect the long-time prognosis of an altruistic kidney donor. Revision of the Japanese donor guidelines concerning acceptable estimation methods for GFR is thought to be needed based on the results of this study.

In this study, we revealed the differences among several kidney function estimation methods for the evaluation of the eligibility of potential donors. The tendency of eGFR $\mathrm{Cr}$ and eGFR-CKDEPI ${ }_{\mathrm{Cr}}$ was to underestimate kidney function and that of eGFR $\mathrm{Cys}_{\mathrm{s}}$ was to overestimate kidney function. The method that most closely aligned with mGFR was $\mathrm{eGFR}_{\mathrm{Cr}+\mathrm{Cys}}$. The reason why Cr-based GFR estimation formulas such as eGFR $\mathrm{Cr}_{\mathrm{r}}$ and eGFR-CKDEPI $\mathrm{Cr}_{\mathrm{r}}$ underestimate kidney function could be due to the characteristics of $\mathrm{Cr}$ behavior, which are affected by muscle volume and food intake as well as glomerular filtration and tubular secretion. CKD patients whose data were used to create GFR estimation formulas, in general, have lower muscle volume and less food intake than a healthy population. Therefore, it has been reported that applying these equations to groups with high GFR could underestimate their renal function. Actually, errors between $\mathrm{C}_{\mathrm{In}}$ and $\mathrm{eGFR}_{\mathrm{Cr}}$ or eGFR-CKDEPI $\mathrm{Cr}$ were significantly large in high $\mathrm{Cr}$ excretion participants. Matsuo et al. reported the possibility that $\mathrm{eGFR}_{\mathrm{Cr}}$ might underestimate kidney function in the population with normal kidney function in a report introducing the Japanese GFR equation [6]. Several other studies concerning kidney function of living kidney donor candidates have presented that eGFR $_{\mathrm{Cr}}$ was lower than mGFR, corroborating our findings in the current study [11-14]. The risk of underestimation should be considered when healthcare professionals use Cr-based equations as a screening criterion for living kidney donors. Although eGFR-CKDEPI ${ }_{\mathrm{Cr}}$ was intended to increase the accuracy in the higher GFR population by using two types of estimation formulas depending on the $\mathrm{Cr}$ value, eGFR-CKDEPI $\mathrm{I}_{\mathrm{Cr}}$ in this study showed no superiority over eGFR ${ }_{C r}$, and eGFR-CKDEPI ${ }_{C r}$ showed a larger deviation from mGFR in the population with good kidney function. For Cys-based testing, eGFR $\mathrm{Cys}_{\mathrm{s}}$ generally showed a higher eGFR value than mGFR, although eGFR Cys did show a more accurate GFR value in kidney donor candidates. However, it is recommended that other kidney function estimation tests be checked when applying estimation formulas to actual candidates, because the deviation of eGFR $\mathrm{Cys}_{\mathrm{s}}$ was relatively large and it is known that Cys might be affected by thyroid function. eGFR $\mathrm{Cr}+\mathrm{Cys}$ did show a value that was closer to mGFR than Cr-based equations and ameliorated the deviations that were shown by eGFR $_{\text {Cys }}$. In fact, eGFR $_{\mathrm{Cr}+\mathrm{Cys}}$ showed the greatest accuracy of all equations investigated in this study. Even though eGFR can be easily checked by a single blood sampling, it is important to know the differences in characteristics between each equation for a more informed and accurate evaluation.

This study suggests that $\mathrm{C}_{\mathrm{Cr}}$ and each GFR estimation formula studied is less accurate in evaluating female participants. One of the reasons is that females, on average, have a significantly smaller body surface area than males. Individuals with smaller body surface areas show larger estimated values than their actual GFR due to the correction factor of $1.73 \mathrm{~m}^{2}$ body surface area. This correction causes tendencies to deviate from mGFR in smaller subjects. If a female with a small body mass is being considered to be a potential living kidney donor candidate, the use of $\mathrm{C}_{\mathrm{Cr}}$ should be avoided for evaluating her kidney function.

This study showed that kidney function could be overestimated or underestimated to varying degrees irrespective of the kidney function estimation method. This finding suggests that it is insufficient to evaluate kidney function using only one estimation method. It is important to use a number of evaluation methods to determine the candidate's adequacy for donation. For example, it stands to reason that the average of eGFR $\mathrm{Cr}$ and eGFR $\mathrm{Cys}_{\mathrm{s}}$ should be used for screening and that mGFR should be used for confirmation. The guidelines recommend $\mathrm{C}_{\mathrm{In}}$ and a radioisotope method for measuring GFR. A radioisotope method is relatively expensive and only limited facilities can perform this testing. Therefore, a more aggressive application of $C_{\text {In }}$ is desired. $C_{\text {In }}$ is one of the most reliable methods for measuring GFR and is considered to be the gold standard. $C_{\text {In }}$ requires no special equipment and can be performed at any facility. Because the $C_{\text {In }}$ measurement method is rather complex, few facilities are performing it currently. However, it is desirable to create an in-hospital system that can measure $C_{\text {In }}$ daily at any facility that performs kidney transplantation.

This study revealed that $\mathrm{C}_{\mathrm{Cr}}$ overestimates kidney function. Therefore, living kidney donors evaluated as adequate for donation using $\mathrm{C}_{\mathrm{Cr}}$ need long-term monitoring to determine whether or not their kidney function worsens after the kidney donation. In particular, as marginal donor cases determined by $\mathrm{C}_{\mathrm{Cr}}$ are considered to have a risk of worsening kidney function, these patients need closer and more long-term follow-up. If cases judged by $\mathrm{C}_{\mathrm{Cr}}$ as marginal donors do not show worsening kidney function through longitudinal observation, de-escalation of the Japanese criteria for living kidney donors might be possible. Longitudinal follow-up of post kidney transplant donors and accumulation of data are required to address this issue definitively. 
This study has several limitations. First, it was conducted with data from a single center, and the collected data were obtained from patients visiting our hospital. Therefore, the results cannot be simply applied to living kidney donor candidates who belong to a super healthy population. Second, perfect urine collection is needed in the process of measuring $C_{\text {In }}$, but residual urine volume in the bladder was not checked in this study. Other GFR affirming methods, such as the radioisotope method, were not conducted in this study because of its retrospective study design. Therefore, there might be some susceptibility to error in the value measured by $\mathrm{C}_{\mathrm{In}}$. In addition, although it is known that Cys is affected by thyroid function, thyroid function could not be checked in all participants because of the retrospective study design. Therefore, this study may contain potential errors.

\section{Conclusions}

Kidney function estimated by $\mathrm{C}_{\mathrm{Cr}}$ is not equal to mGFR. When using $\mathrm{C}_{\mathrm{Cr}}$ as a kidney function estimation method to determine the adequacy of a living kidney donor, consideration that $\mathrm{C}_{\mathrm{Cr}}$ might overestimate kidney function is required. It is important to combine multiple eGFR values calculated by each equation to evaluate deviation. Particularly in the case of evaluating the adequacy of marginal donor, GFR estimated by $\mathrm{C}_{\mathrm{In}}$ should be required.

\section{Appendix}

Impact of creatinine excretion on estimation accuracy

Appendix shows scatter plots for $\mathrm{C}_{\mathrm{In}}$ and other kidney function estimation models dividing into $\mathrm{Cr}$ excretion amount. A; CIn and $\mathrm{CCr}$, low $\mathrm{Cr}$ excretion group, B; CIn and $\mathrm{CCr}$, high $\mathrm{Cr}$ excretion group, $\mathrm{C}$; $\mathrm{CIn}$ and eGFRCr, low $\mathrm{Cr}$ excretion group, D; CIn and eGFRCr, high $\mathrm{Cr}$ excretion group, E; CIn and eGFRCys, low $\mathrm{Cr}$ excretion group, F; CIn and eGFRCys, high Cr excretion group, G; $\mathrm{CIn}$ and eGFRCr+Cys, low $\mathrm{Cr}$ excretion group, $\mathrm{H}$; $\mathrm{CIn}$ and eGFRCr+Cys, high $\mathrm{Cr}$ excretion group, I; CIn and eGFR-CKDEPICr, low $\mathrm{Cr}$ excretion group, J; CIn and eGFR-CKDEPICr, high Cr excretion group. For reference, auxiliary line which equal to CIn was presented. For reference, auxiliary line which equal to $C_{\text {In }}$ was presented.

\section{Abbreviations}

$C_{C r}$ : Creatinine clearance; $C_{\mid n}$ : Inulin clearance; CKD: Chronic kidney disease; CKD-EPI: The Chronic Kidney Disease Epidemiology Collaboration;

Cr: Creatinine; Cys: Cystatin C; eGFR: Estimated GFR; eGFR-CKDEPI ${ }_{C r}$ : eGFR as

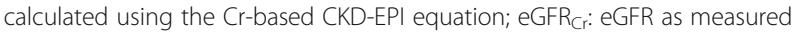
by creatinine; eGFR Cr+Cys: Average of eGFR $_{C r}$ and eGFR cys; eGFR cys: eGFR as measured by cystatin C; GFR: Glomerular filtration rate; In: Inulin; mGFR: Measured GFR
}

\section{Acknowledgments}

The authors would like to thank Editage (www.editage.com) for English language editing.

\section{Authors' contributions}

$\mathrm{KH}$ contributed to the research idea and study design. $\mathrm{KH}, \mathrm{MH}, \mathrm{TM}$, TO, and IO contributed to the data acquisition. MS contributed to measure collected samples. $\mathrm{KH}$ and $\mathrm{YY}$ contributed to the data analysis. $\mathrm{KH}$ wrote the manuscript. OI and YK corrected the manuscript, tables, and figures. YK is the research director. All authors read and approved the final manuscript.

\section{Funding}

Not applicable.

\section{Availability of data and materials}

The datasets used and analyzed concerning this study are available from the corresponding author on reasonable request.

\section{Ethics approval and consent to participate}

The study protocol was approved by the institutional review board of the ethical committee at Shinshu University Hospital (approval no. 3384) and was conducted in accordance with the principles contained within the Declaration of Helsinki as revised in 2013.

Consent for publication

Not applicable.

\section{Competing interests}

The authors declare that they have no competing interests.

\section{Author details}

'Department of Nephrology, Shinshu University School of Medicine, 3-1-1 Asahi, Matsumoto 390-8621, Japan. ${ }^{2}$ Department of Laboratory Medicine, Shinshu University Hospital, Matsumoto, Japan. ${ }^{3}$ Department of Urology, Shinshu University School of Medicine, Matsumoto, Japan.

Received: 26 July 2019 Accepted: 26 December 2019

Published online: 13 January 2020

\section{References}

1. Yagisawa T, Mieno M, Ichimaru N, Morita K, Nakamura M, Hotta K, Kenmochi T, Yuzawa K. Trends of kidney transplantation in Japan in 2018: data from the kidney transplant registry. Ren Replace Ther. 2019;5:3.

2. Morozumi K, Ichimaru N, Katayama A, Goto N, Shishido S, Shibagaki Y, Tanabe K, Nishi S, Hattori M, Harada H, Minakuchi J, Watarai Y. Guidelines for Japanese living kidney donors. 2014. http://www.asas.or.jp/jst/pdf/manual/ 008.pdf

3. Ethics Committee of the Transplantation Society. The consensus statement of the Amsterdam Forum on the Care of the Live Kidney Donor. Transplantation. 2004 Aug 27;78(4):491-2.

4. Clinical Practice Guidebook for Diagnosis and Treatment of Chronic Kidney Disease 2012. Nihon Jinzo Gakkai Shi. 2012;54(8)

5. Horio $M$, Imai $E$, Yasuda $Y$, Hishida A, Matsuo $S$. Simple sampling strategy for measuring inulin renal clearance. Clin Exp Nephrol. 2009 Feb;13(1):50-4.

6. Matsuo S, Imai E, Horio M, Yasuda Y, Tomita K, Nitta K, Yamagata K, Tomino Y, Yokoyama H, Hishida A. Revised equations for estimated GFR from serum creatinine in Japan. Am J Kidney Dis. 2009 Jun;53(6):982-92.

7. Horio M, Imai E, Yasuda Y, Watanabe T, Matsuo S. GFR estimation using standardized serum cystatin C in Japan. Am J Kidney Dis. 2013 Feb;61 (2):197-203.

8. Horio M, Imai E, Yasuda Y, Watanabe T, Matsuo S. Performance of GFR equations in Japanese subjects. Clin Exp Nephrol. 2013 Jun;17(3):352-8.

9. Levey AS, Stevens LA, Schmid CH, Zhang YL, Castro AF 3rd, Feldman HI, Kusek $J W$, Eggers P, Van Lente F, Greene T, Coresh J. A new equation to estimate glomerular filtration rate. Ann Intern Med. 2009 May 5;150(9):604-12.

10. Soveri I, Berg UB, Björk J, Elinder CG, Grubb A, Mejare I, Sterner G, Bäck SE. Measuring GFR: a systematic review. Am J Kidney Dis. 2014 Sep;64(3):411-24.

11. Kakuta Y, Okumi M, Ichimaru N, Abe T, Nonomura N, Okuyama A, Kojima Y, Isaka Y, Takahara S, Imai E, Horio M. Utility of the Japanese GFR estimation equation for evaluating potential donor kidney function. Clin Exp Nephrol. 2010 Feb;14(1):63-7.

12. Horio M, Yasuda Y, Kaimori J, Ichimaru N, Isaka Y, Takahara S, Nishi S, Uchida K, Takeda A, Hattori R, Kitada H, Tsuruya K, Imai E, Takahashi K, Watanabe T, Matsuo S. Performance of the Japanese GFR equation in potential kidney donors. Clin Exp Nephrol. 2012 Jun;16(3):415-20. 
13. Tsujimura K, Shirakawa H, Tokumoto T, Endou M, Wakai S, Ishida H, Tanabe K. Utility of the Japanese glomerular filtration rate equation in estimating glomerular filtration rate of donor kidney. Transplant Proc. 2016 Apr;48(3):734-7.

14. Horio M, Yasuda Y, Kaimori J, Ichimaru N, Kakuta Y, Isaka Y, Matsuo S,

Takahara S. Performance of the Japanese glomerular filtration rate equation based on standardized serum cystatin $\mathrm{C}$ in potential kidney donors.

Transplant Proc. 2014;46(2):314-7.

\section{Publisher's Note}

Springer Nature remains neutral with regard to jurisdictional claims in published maps and institutional affiliations.

Ready to submit your research? Choose BMC and benefit from:

- fast, convenient online submission

- thorough peer review by experienced researchers in your field

- rapid publication on acceptance

- support for research data, including large and complex data types

- gold Open Access which fosters wider collaboration and increased citations

- maximum visibility for your research: over $100 \mathrm{M}$ website views per year

At $B M C$, research is always in progress.

Learn more biomedcentral.com/submissions 